\title{
DA ESCURIDÃO À CEGUEIRA DA LUZ: ENSAIOS SOBRE A CEGUEIRA EM ANDRÉ CARNEIRO E JOSÉ SARAMAGO
}

\author{
Gladson Fabiano de Andrade Sousa ${ }^{1}$ \\ Naiara Sales Araujo Santos ${ }^{2}$ \\ Rita de Cássia Oliveira ${ }^{3}$
}

\begin{abstract}
Resumo: Em 1963, o escritor brasileiro André Carneiro publica seu conto $A$ escuridão, que traz a história de um fenômeno que desafia a ciência: toda fonte de luz, natural ou artificial, não ilumina mais. Sol, fósforos, lanternas se mostram inúteis; assim recai sobre a terra uma escuridão sem precedentes. Mais de trinta anos depois, o escritor português José Saramago lança seu Ensaio sobre a cegueira, romance que traz o drama de um mundo repentinamente afligido por uma epidemia referenciada como "cegueira branca". Sobre estes semelhantes motes, os autores contemporâneos abrem seus universos ficcionais refletindo sobre a condição humana e como a sua natureza é revelada ao ruir das convenções político-sociais. O presente artigo tem como objetivo analisar os pontos de convergência e divergência entre as obras $A$ escuridão e Ensaio sobre a cegueira, a partir da perspectiva da obra Dialética do esclarecimento (1944) de Adorno e Horkheimer, bem como das discussões acerca da Fiç̧ão Científica apresentadas pela crítica literária Elizabeth Ginway. Serão consultadas também os apontamentos do sociólogo Zygmunt Bauman (2003).
\end{abstract}

Palavras-chave: André Carneiro. José Saramago. Cegueira. Dialética do esclarecimento.

\section{INTRODUÇÂO}

A literatura como arte que se fundamenta na mimese, como descreveu Aristóteles em sua Poética, (re)cria o mundo, ou a visão de mundo de um autor, concebendo reflexões sobre o que foi, o que é, e o que será. Os fatos históricos, por mais que estejam consolidados no discurso, ou nos autos, são tensionadas, questionadas, ou até mesmo, subvertidas pelo fazer literário. Assim, encontramos uma relação mimética peculiar da literatura com a história. Não menos instigante é a relação da literatura com a história que ainda estar por vir. Nesse contexto, o gênero ficção científica (doravante FC) se apresenta como exemplar, pois discorre sobre as especulações de mundos futuros, ou possibilidades dos caminhos da humanidade, atrelados à ciência e tecnologia.

A FC cria mundos verossimilhantes, simulações de onde o presente pode nos levar. As narrativas futuristas guardam em suas invenções e descobertas científicas, em suas especulações e extrapolações, a mimese de um mundo real e

\footnotetext{
${ }^{1}$ Mestrando pelo Programa de Pós-Graduação em Letras da Universidade Federal do Maranhão PPGLetras/UFMA. E-mail: gladdking@hotmail.com

2 Doutora em Literatura Comparada pela Universidade Metropolitana de Londres. E-mail: naiara.sas@gmail.com

3 Doutora em Filosofia pela Pontifícia Universidade Católica de São Paulo. E-mail: ritaoliveira@yahoo.com
}

Revista de Letras JUÇARA, Caxias - Maranhão, v. 02, n. 01, p. 206 - 223, jul. 2018| 206 
palpável. Nesse sentido, podemos citar a obra de Júlio Verne Da Terra à Lua (no original em francês De la Terre à la Lune) de 1865, que narra a façanha de uma viagem tripulada à lua, o que viria a ocorrer mais de cem anos depois.

Historicamente, vemos algumas curiosas semelhanças entre a obra de Verne e o que de fato ocorreu: ambos os módulos lançados à lua foram tripulados por três astronautas, e, o local da partida do "foguete" da obra de Verne dista apenas $30 \mathrm{~km}$ de onde de fato Apolo 11 partiu. Mesmo quando trata do passado, a FC abre portas a possibilidades de mundos paralelos que nos levam a reflexões sobre o presente. Outro exemplo é O presidente negro (1926), de Monteiro Lobato, que se passa no futuro de 2228 abordando a disputa entre um negro e uma mulher pela presidência dos Estados Unidos. Dentre muitas especulações, uma nos leva a fazer alusão aos feitos do homem a partir da existência da internet:

\footnotetext{
.... radiotransporte tornará inútil o corre-corre atual. Em vez de ir todos os dias o empregado para o escritório e voltar pendurado num bonde que desliza sobre barulhentas rodas de aço, fará ele o seu serviço em casa e o radiará para o escritório. Em suma: trabalhar-se-á a distância. E acho muito lógica esta evolução. (LOBATO, 2008, p. 65).
}

A especulação encontra suas bases no real e partindo deste ponto, extrapola conceitos, teorias e leis. Aparentemente contraditórios, ciência e ficção fundem-se no gênero da FC, que toma em especial para si o exercício das especulações, e, principalmente, a relação do homem com seu avanço (ou não) científico-tecnológico.

O presente artigo tem como objetivo principal tecer uma análise comparada de duas obras que especulam a respeito de um acontecimento mundial sem precedentes: a cegueira, temática presente no conto $A$ escuridão de André Carneiro, publicado em 1963, no livro de contos Diário da nave perdida; e no romance Ensaio sobre a cegueira de José Saramago, publicado em 1995. Ambas as obras utilizam a cegueira como mote para desencadear reações e revoluções profundas nos indivíduos, e, por conseguinte, na sociedade, porém cada uma de forma distinta, e com visões destoantes a respeito da natureza humana.

Assim, pretende-se discutir classificações ou enquadramento das obras em gêneros ou subgêneros da literatura especulativa, focando sobretudo nas temáticas que nos possibilitam enquadrá-las no gênero de FC. A estudiosa de FC Elizabeth 
Ginway declara, em seu livro Ficção científica brasileira: mitos culturais e nacionalidade do País do Futuro (2005), que utilizou a definição de FC a partir da “iconografia" do gênero, feita por Gary K. Wolfe, na qual certos "ícones” recorrentes - robô, alienígena, espaçonave, cidade, e a terra devastada, - são tomados como os indicadores mais confiáveis da filiação de um texto ao gênero. O mundo devastado por uma praga, ou uma guerra mundial, torna-se matéria fecunda para a FC.

As obras analisadas apresentam um olhar de desconfiança em relação as possíveis explicações científicas dos estranhos eventos que causam o pânico mundial, assim, o diálogo da sociedade com a ciência e a tecnologia mostra-se conflitante e determinante nas ações das personagens em cada narrativa. Ao longo da análise, serão ressaltados os pontos de convergências e divergências presentes nas duas obras, no tocante às temáticas oriundas do diálogo sociedade e desenvolvimento tecnocientífico.

A análise será feita a partir das perspectivas apresentadas na obra Dialética do esclarecimento (1985) dos filósofos Adorno e Horkheimer, utilizando o conceito de esclarecimento (aufklärung) e as concepções de sociedade contemporânea que exalta o excessivo uso da razão como caminho único para a verdade ou pretensa evolução. Tais concepções servirão de material interpretativo para as relações tecidas nas obras entre o homem e a ciência, e as consequências desta relação para o convívio humano.

Neste contexto, a análise será pautada no que se pode chamar de tese central, ou angústia central, da Dialética do esclarecimento, que nas palavras dos filósofos justifica-se pela necessidade de "descobrir por que a humanidade, em vez de entrar em um estado verdadeiramente humano, está se afundando em uma nova espécie de barbárie”. (ADORNO \& HORKHEIMER, 2006, p.11)

De acordo com os filósofos, o homem torna-se prisioneiro desta razão técnica que constrói ciência e tecnologia, mas que não é capaz de contribuir para a evolução humana em relação a moral e a ética. Até que ponto o desenvolvimento tecnocientífico levou o homem um verdadeiro progresso? A barbárie no contexto dos filósofos da Escola de Frankfurt é a II Guerra Mundial. Com base no conceito de esclarecimento dissertado por Immanuel Kant, em seu artigo $O$ que é esclarecimento? (Was ist Aufklaerung?) publicado em 1784, e retomado por Adorno 
e Horkheimer, a análise a seguir será pautada no questionamento deste esclarecimento que representa a "saída do homem de sua menoridade" (KANT, 1985, p.100). Intenta-se demonstrar sobretudo, que este tema, tão caro à filosofia do século XX, o qual coloca a obra Dialética do esclarecimento (2005) como um clássico da filosofia moderna, também inquietou, e inquieta, os escritores da modernidade.

\section{A BARBÁRIE DA RAZÃO}

A princípio devemos estabelecer as relações que aproximam e distanciam as duas obras no que diz respeita ao fenômeno estranho que repentinamente assola a vida dos moradores de lugares sem nomes. Em ambas as obras não há identificação dos lugares onde ocorrem os fatos, sabe-se, através das descrições, que são cidades do mundo moderno com seus trânsitos e buzinas, vias apinhadas de transeuntes e labirintos prediais, ou seja, representações típicas de qualquer metrópole moderna.

A escuridão apresenta a personagem principal Wladas, o qual possui personalidade cética, é um típico indivíduo moderno, que crê na racionalidade científica, razão pela qual só "aceitou a realidade do fenômeno mais tarde do que os outros. Era solteiro, distraído e muito prático". (CARNEIRO, 1963, p. 115). Neste conto, o motivo da cegueira é um fenômeno que desafia explicações científicas: o sol não emite mais luminosidade, nem qualquer outro foco de luz, muito menos emite calor.

Assim a Terra é tomada por completa treva. Eis o estopim da desestruturação das convenções sociais; os indivíduos são obrigados, por acidentes e por questão de sobrevivência a se deparar com o outro, o que os leva a um processo contínuo de redescoberta ou revelação da essência humana. Esse processo de redescoberta humana se configura de modo distinto em cada obra.

Em Ensaio sobre a cegueira, como já dito, não há identificação do país em que ocorre o fato; essa indeterminação na narrativa saramaguiana faz parte dos elementos que compõem o jogo indentitário como um todo, onde nem mesmo as personagens possuem nomes. Compete à presente análise ressaltar que as referências são feitas pela relação que uma personagem tem com o outro (a mulher 
do médico), pelo papel social que este desempenha (o taxista, o policial) ou, ainda, por um dado observável (rapariga de óculos escuros).

A cegueira neste caso é causada também por um fenômeno que a ciência não consegue explicar, repentinamente as personagens começam a enxergar tudo branco, assim, a doença é batizada de "mal branco" ou "mar de leite". Inicia-se, então, o drama mundial, pois todos que entram em contato com os acometidos pelo mal, ainda que sem vetor evidente, rapidamente também cegam. O clima do medo e a sensação de eminente cegueira perpassam as relações das personagens.

Apresentamos em paralelo uma cegueira negra e uma cegueira branca, antítese com a qual pode-se tecer importantes considerações. Destaca-se aqui tais expressões que fazem referências à luz, ou a falta dela, como metáforas de esclarecimento, no sentido da saída do homem das trevas da ignorância, alcançando sua autonomia crítica e racional. Sentido este, base da crítica da obra Dialética do esclarecimento, na qual Adorno e Horkheimer (2006) buscaram as raízes da racionalidade na sociedade ocidental, desde os mitos até a dominação da natureza, apontando-a como responsável pela alienação do homem.

O que está sendo colocado em xeque pelos filósofos é simplesmente o movimento do lluminismo, processo que vem desde à antiguidade clássica, passando pelo logos que destituiu os deuses do Olimpo como coerência mágica que explicava o mundo e seu funcionamento (ROUANET, 2004), até a llustração do Século XVIII, que "realiza a abolição dos deuses em sua marcha cientificista, solapa a construção mitológica." (MERQUIOR, 2017, p. 59). Para Adorno e Horkheimer o lluminismo, como afirma José Guilherme Merquior (2017), não é apenas um movimento intelectual da era moderna,

\footnotetext{
...é antes a direção fundamental do espírito humano expressa na visão científico-utilitária da realidade, e imposta desde o ingresso da humanidade nos tempos históricos. lluminista é o ânimo de assenhoramento da matéria, é o imperialismo da vontade humana que atua apoiada na abstração do real desenhada pela ciência [...] $O$ verdadeiro objetivo iluminista não é tanto o conhecer quanto o agir da produção industriosa: o conhecimento como poder. (MERQUIOR, 2017, p.59).
}

Ressaltam, os filósofos, o objetivo do esclarecimento desde sua origem foi livrar o homem do medo e torná-lo senhor da natureza. Porém, dialeticamente, esta superação também traz em si o signo de uma calamidade triunfal. Os autores 
apontam que o programa do esclarecimento era, em termo weberiano, o desencantamento do mundo, tendo como meta dissolver os mitos e substituir a imaginação pelo saber. Apontam ainda que os mitos, que são vítimas do esclarecimento, já eram o produto do próprio esclarecimento que "reconheceu o legado platônico e aristotélico da metafísica, assim instaurou-se um processo contra a pretensão da verdade universal" (ADORNO \& HORKHEIMER, 2006, p.21). Todo e qualquer conhecimento que não se submete ao critério da calculabilidade e da utilidade torna-se suspeito para o esclarecimento. Não se nega o pensamento esclarecedor como condição da liberdade na sociedade,

\begin{abstract}
contudo, acreditamos ter reconhecido com a mesma clareza que o próprio conceito desse pensamento, tanto quanto as formas históricas concretas, as instituições da sociedade com as quais está entrelaçado, contém o germe para a regressão que hoje tem lugar por toda parte. Se o esclarecimento não acolhe dentro de si a reflexão sobre esse elemento regressivo, ele está selando seu próprio destino. Abandonando a seus inimigos a reflexão sobre 0 elemento destrutivo do progresso, 0 pensamento cegamente pragmatizado perde seu carácter superador e, por isso, também sua relação com a verdade. (ADORNO \& HORKHEIMER, 2006, p.13).
\end{abstract}

Então um conhecimento que está sujeito à práticas de poder perde sua finalidade de desatar o homem da ignorância, libertando-o na direção da razão crítica, autônoma. A autodestruição do esclarecimento desenvolve-se no conceito de Indústria Cultural discorrido pelos filósofos, pois tal indústria reduz o esclarecimento em ideologia, através de alienantes serviços e produtos massificados.

O esclarecimento consiste neste ponto, sobretudo, "no cálculo da eficácia e na técnica de produção e difusão [...] a ideologia se esgota na idolatria daquilo que existe e do poder pelo qual a técnica é controlada. (ADORNO \& HORKHEIMER, 2006, p.16). A obra Dialética do esclarecimento faz duras críticas ao excesso de razão da cultura ocidental que dentro do sistema capitalistas torna o homem idólatra da razão que produz cultura técnica.

O que de início serviu para tirar o homem das trevas, e vencer o medo da escuridão e do desconhecido, já guardava em sua essência de domínio tecnológico da natureza a falência de uma vida verdadeira humana, assim, sendo esta guiada por uma razão totalitária. O mundo torna-se administrado por uma lógico de espíritos sem finalidades, ainda que a sociedade esteja mais lúcida quanto a seus 
meios e recursos, esta é cega a essência de sua ação (MERQUIOR, 2007). Através da faca da Industria Cultural Adorno e Horkheimer apontam o câncer na sociedade, o mal da domesticação do homem; o conformismo e consumismo das massas torna-se o paradigma da sociedade.

Os conhecimentos que não recaem sobre as medidas da razão técnica são tachados de obscuros ou irreais, não carecendo, assim, de atenção. Nesse sentido, o conceito de esclarecimento mantém "o espírito sob o domínio da mais profunda cegueira", (ADORNO \& HORKHEIMER, 2005, p.14). No mundo administrado por interesses de consumo, a razão é construída socialmente e ligada a valores imbricados ao crescimento e manutenção deste. O mundo cega-se à tal clareza, que idolatra a razão e repudia tudo o que não se pode racionalizar, ou transformar em produto.

\section{A CHÁCARA MODELO E O MANICÔMIO: ENTRE A IRONIA DA EVOLUÇÃO À BARBÁRIE}

A despeite da cegueira de ambas as obras, a análise dos espaços nos quais ocorrem os conflitos das personagens nos traz relevantes contribuições para o presente entendimento das mesmas. Ambas colocam em evidência a figura dos que já eram cegos antes mesmo dos fenômenos inexplicáveis pela ciência. A irônica inversão de papéis entre os "recentes cegos" e os que já eram cegos leva Wladas, protagonista, a sensibilizar-se da condição do outro, resgatando o abandonado sentimento de alteridade. Wlades vê-se no lugar daqueles, que imersos na frenética rotina da cidade, são ignorados, senão, desprezados pelos ditos "saudáveis" dos olhos, que transitam e não o veem. Aqueles que estão à margem da dependência alheia.

Aqueles mesmos homens de bengala branca e óculos escuros que perguntavam humildemente qual o ônibus que vinha, ou se distanciavam devagar, atravessando os olhares piedosos dos passantes, eram agora rápidos, e pacientes, milagrosos com sua habilidade manual. (CARNEIRO, 1963, p.150).

Vê-se neste trecho a reflexão sobre os marginalizados por um mundo metropolitano onde o sentimento de alteridade foi perdido, pois o outro é entendido como o inimigo, como aquele que incita insegurança; o medo e falta de segurança 
são sentimento típicos dos que vivem em sociedade. Segundo o sociólogo polonês Zygmunt Bauman (2003), viver em sociedade configura condição contrário do que significa viver em comunidade. O sociólogo da chamada modernidade líquida descreve as relações e laços fraternos como cada vez mais transitórios e flexíveis, antítese para o mundo sólido anterior ao século XX, no qual o mundo mudava em progressão mais lenta, e o processo de globalização ainda engatinhava.

Neste contexto, em sua obra Comunidade: a busca por segurança no mundo atual (2003), Bauman elucida a dicotomia semântica entre "viver em comunidade" e "viver em sociedade". Segundo ele, "numa comunidade, todos nós entendemos bem, podemos confiar no que ouvimos, estamos seguros a maior parte do tempo, ou raramente ficamos desconcertados ou somos surpreendidos" (BAUMAN, 2003, p.8).

$\mathrm{Na}$ antiguidade, o homem para se proteger, melhorar as condições de vida e principalmente buscar alternativa de alimento além da caça, abandona a vida nômade, surgindo assim as primeiras cidades. A estrutura urbana na qual o homem buscou tal melhoria de vida e segurança transformou-se em grandes metrópoles, lugares onde o aglomerado, o excesso de ruídos, a estrutura labiríntica e muitas vezes de pouca luz, incita o medo e a insegurança.

Nesta Perspectiva, a relação do homem com o outro não se configura como a relação de reconhecimento, ressaltada por Bauman (2003) como "relação de comunidade", mas sim a sensação de vigilância pelo latente sentimento que na próxima esquina um perigo espreita. De tal relação é que provém a, cada vez mais comum, organização urbana em condomínios, câmeras de segurança (vigilância), muros altos, cercas elétricas, e todos os apetrechos tecnológicos que buscam o retorno do sentimento de segurança. Essa estrutura é citada nas obras aqui analisadas. $O$ cenário é urbano onde predominam os altos prédios que escondem a luz.

$\mathrm{Na}$ escuridão, o labirinto de prédios impende o trânsito humano. Wladas tenta chegar até onde reside sua irmã, porém, em meio a escuridão, as inúmeras ruas e becos se mostram perigosos; com medo de perder-se, desiste, apesar de sua irmã morar apenas a três quarteirões de distância. $O$ caos dos centros urbanos também é evidente em Ensaio sobre cegueira, pois a cegueira branca desencadeia reações de violência em massa, as pessoas vagam perdidas nas ruas da cidade, 
digladiando-se por qualquer abrigo e comida. A noção de propriedade é conflituosa; em busca da sobrevivência casas e prédios são invadidos.

Wladas, representante de uma sociedade esclarecida, racional e prática, uma vez privado da luz e perdido em meio às ruas da cidade, conhece Vasco, que não the nega ajuda, como guia em meio à escuridão. Notando o quão confiante o estranho caminha em meio a escuridão, Wladas descobre que Vasco é cego de nascença, por isso, já acostumado com a situação. Fortalecendo a visão distinta que cada autor possui da natureza humana, nota-se as atitudes dos que já eram cegos antes do inexplicável fenômeno em cada obra.

Em A escuridão, Vasco - como não aludir o explorador português Vasco da Gama?! - guia Wladas no seu caminho, acolhe este e os recém conhecidos na chamada Chácara Modelo. Os cegos que já moravam neste instituto são descritos como gentis e solícitos; dividem-se e cada um fica responsável por guiar um pequeno grupo em suas atividades sanitárias, agrícolas, entre outras. Assim, a pequena comunidade vai reaprendendo a sobreviver em cooperativa. Nota-se a alusão ao "Modelo", no nome da chácara, modelo cooperativista de organização humana a ser aprendido e seguido.

Em contraponto tem-se o cego de Ensaio sobre a cegueira, que adaptado à situação, logo junta-se ao grupo que sitiara o manicômio, - internato que o Governo providenciara aos acometidos pelo "mal branco" - exercendo a função de contabilizar e registrar em braile os pertences como dinheiro, relógio e joias que abusivamente exigiam dos demais em troca de comida. Logo após o assassinato do chefe do bando, cometido pela mulher do médico, o cego toma a chefia e promete vingar-se, advertindo que não era um cego igual aos demais, pois "quando vocês cegaram já eu conhecia tudo do mundo, da minha cegueira não sabes nada" (SARAMAGO, 2005, p. 188).

É perceptível o distanciamento das ações dos cegos de nascença nas obras analisadas: enquanto um é solidário, o outro deseja somente tirar vantagem de sua adaptação à cegueira. No entanto, em determinada proporção, em ambas as obras, a escuridão serve para o que podemos chamar de catarse dos laços humanos, ou o ressurgimento dos sentimentos de comunidade.

Após findar o estranho fenômeno da escuridão - sem nenhuma explicação de sua origem ou por que findara - com as lições aprendidas na pequena sociedade 
rural, Wladas retorna à cidade, porém agora convertido com a sensação de que não era o mesmo de antes, retorna agora mais humanizado, e menos crente nas suas certezas científicas. Como apontara Ginway (2005), o que aconteceu a Wladas é semelhante à conversão de São Paulo que cegou temporariamente na estrada para Damasco. Ginway aponta também que a originalidade de $A$ escuridão consiste na visão que o autor tem de cidade moderna que se choca com a visão tradicional da ficção científica americana, pois

...o típico papel da cidade é impedir os humanos de alcançarem o progresso futuro. A visão de futuro de Carneiro não inclui a superpopulação, oferecendo um tipo de equilíbrio entre a vida civilizada e a vida primitiva. A escuridão facilita a organização de pequenos grupos sociais, que por sua vez, fornecem esperança de sobrevivência na complexidade labiríntica da cidade moderna. (GINWAY, 2005, p.86).

Enquanto em André Carneiro a cegueira significa a origem da redescoberta desses valores de humanidade, Saramago tece um panorama onde a claridade excessiva e totalitária nos leva a barbárie, onde a sobrevivência não é cooperativa, mas individualista. As tentativas de cooperação que surgem em Ensaio Sobre Cegueira logo são suplantadas ora pela milícia, que possui um membro nascido cego, o qual tira proveito da situação por já está adaptado a não enxergar, ora pelo oportunismo: como a situação que ocorre logo no início da narrativa no caso do ladrão de carro, que se oferece para levar o recém cego em casa e furta-lhe o carro.

Em ambas, vemos a crítica à racionalidade científica enquanto elemento que salva o homem, visão típica da clássica ficção científica hard. Esta vertente valoriza as descrições externas, utiliza-se dos ícones da FC como robôs e espaçonaves, e encontra a solução dos problemas do enredo através das ciências Hard como biologia, física, química. A ficção científica clássica glorifica a racionalidade: a elevação da razão e do intelecto levam-na a reprimir a emotividade e a negar motivações subconscientes ou irracionais (HUNTINGTON apud GINWAY, 2005, p.38), a despeite desta tradição da FC, André Carneiro foca seu enredo em tais motivações e emotividade. Eis um dos pontos de divergência entre a FC brasileira e a tradição clássica.

Ponto o qual aproxima tanto as obras brasileira e portuguesa: ambas não enveredam pelas ciências Hard, que popularizaram mundialmente as histórias de 
FC, mas dão desenvolvimentos às emoções e conflitos humanos. Em relação ao tema das obras, tornou-se tradição dentro da FC, o tópico da terra devastada (GINWAY, 2005). A própria cegueira coletiva pode ser considerada um tópico dentro da literatura em geral. Se buscarmos sua genealogia perder-se-ia de vista os propósitos do presente estudo, mas temos pontualmente exemplos como o romance de FC do escritor britânico John Wyndham, O dia das Trífides, de 1951, o qual transmite as tensões da Guerra Fria e as consequências maléficas do desenvolvimento científico para a humanidade. Neste romance uma raça mutante de plantas elaboradas com fins comerciais possui cognição e capacidade de deslocamento, porém foge do controle dos cientistas e ameaça a vida humana. Neste contexto, um acidente, colisão entre um meteoro e um satélite, causa uma cegueira coletiva, gerando o caos.

Temos também o conto moral Em terra de cego de H. G. Wells, originalmente publicado em 1904, pela The Strand Magazine, no qual, por isolamento geográfico, um comunidade desenvolve-se isoladamente onde todos são cegos, até chegar um dia um explorador com a capacidade de enxergar, gerando conflito com os dogmas daquela comunidade, e logo este é ridicularizado e excluso. O próprio conto de Wells, retomam a alegoria da caverna platônica.

Contrária à vertente FC Hard, a chamada New Wave da FC faz uso das ciências Soft como psicologia, sociologia e antropologia. Detalhes do instrumental tecnológico ou leis físicas são deixados em segundo plano. Em ambas as narrativas, por ora analisadas, o fenômeno da escuridão e da cegueira branca permanecem inexplicáveis; foca-se nas personagens, seus relacionamentos e sentimentos.

Encontramos em $A$ escuridão e Ensaio sobre a cegueira o foco nos sentimentos e relações humanas exaltando os conhecimentos referentes aos estudos de psicologia, sociologia e antropologia. André Carneiro, em especial, é um dos primeiros expoentes brasileiro da FC Soft, já evidenciado tanto pela crítica especializada nacional quanto internacional, como afirma o escritor e crítico de FC brasileira Roberto de Sousa Causo:

Carneiro foi um dos primeiros autores brasileiros a produzir uma narrativa que se aproximava da FC da chamada New Wave inglesa [...] pela exploração ousada "o espaço interior" da pisque humana, em oposição a ênfase no espaço exterior da FC convencional. Histórias como [...] o seu 
clássico "A escuridão (1963), em que que a realidade é um processo fluído e relativo, levaram o escritor e editor americano Harry Harrison a comentar: "O que acho particularmente interessante é que a escrita de Carneiro se preocupa com a abordagem da realidade, "o espaço interior" de J.G. Ballard" (CAUSO, 2009, p.57).

Tal tendência mais humana da FC na literatura brasileira da década de 60 que é explorada na obra de Carneiro é apontada também por Elizabeth Ginway. Para a estudiosa, os escritores brasileiros demonstram desconfiança sobre os aspectos da ciência e tecnologia nas mãos dos humanos, "por conta de falta de confiança no poder da razão em controlar os excessos das emoções humanas" (GINWAY, 2005, p.39).

Por vezes, os aspectos de glorificação da razão típicos das narrativas de FC hard são negados por conta da aguda divisão de classes na sociedade brasileira e da concentração de poder e de dinheiro entre a elite tradicional, que se intensificaram mais durante o processo de modernização brasileira na ditadura militar. Vale ressaltar que André Carneiro publica sua obra durante a Guerra Fria, época de suspeita das implicações benéficas da tecnologia para a vida humana (mesmo período que escreviam os autores da Escola de Frankfurt).

Considerando a atmosfera de desconfiança em relação a ciência e seus resultados benéficos ou maléficos para a vida em comunidade, podemos tecer um paralelo entre a Chácara Modelo, espaço de preservação coletiva e subsistência de $A$ escuridão, e o local escolhido pelo Governo em Ensaio sobre a cegueira para "acolher" os cegos e os possivelmente contaminados pelo mal branco. Enquanto Carneiro apresenta um espaço onde os laços humanos se intensificam em prol de uma adaptação e sobrevivência sadia, Saramago apresenta um ambiente regido pelas leis sanitárias, determinadas por estudos científicos.

O narrador saramaguiano declara com cinismo e ironia que a ideia saíra da própria cabeça do ministro, "uma ideia feliz, senão perfeita, tanto no que se referia aos aspectos meramente sanitários do caso como às suas implicações sociais e aos seus derivados políticos. (SARAMAGO, 1995, p. 45). O manicômio é eleito com melhores propriedades para o intendo de manter (conter) os enfermos em um lugar sanitário, social e politicamente seguro. Compara-se tal situação à antiga prática, herdada dos tempos da cólera e da febre-amarela, quando "os barcos contaminados ou só suspeitos de infecção tinham de permanecer ao largo durante 
quarenta dias, até ver" (Idem), alusão à clássica Stultifera Navis ou Naus dos insensatos.

Foucault, em História da Loucura na Idade Clássica (2008) utiliza desta alegoria medieval para elucidar os jogos de exclusão e poder que se processam na história da loucura na sociedade ocidental, pois nestas eram depositados os pobres, vagabundos, bêbados, devassos, presidiários, todos que assumiram o papel abandonado pelos lazarentos depois do século XIV. No século XVI e XVII ocorre o que Foucault chama de $A$ Grande Internação, os chamados Hospitais Gerais se proliferam pela Europa, que vêm a abrigar estes "alienados" sociais:

O Hospital Geral é um estranho poder que o rei estabelece entre a polícia e a justiça, nos limites da lei é a terceira ordem da repressão. [...] em seu funcionamento ou em seus propósitos, o Hospital Geral não se assemelha a nenhuma ideia médica. É uma instância de ordem, da ordem monárquica e burguesa [...]. Está diretamente ligado ao poder real... (FOUCAULT, 2008, p. 50).

A analogia é evidente em Ensaio sobre a cegueira, o ministro ao decretar que o manicômio é o lugar perfeito para a quarentena, não constitui somente um ato de precaução para a saúde pública, mas também representa exercício do poder do Governo sobre àqueles que não lhe são mais úteis ou que estão a margem. Foucault ( 2008) elucida o jogo de poder que tais manicômios encerram, pois representam atos sociais e políticos; aparelhos repressivos de condutas socialmente inaceitáveis, pela própria parcela de diferentes pessoas que eram enclausuradas; tais casas destinavam-se a socorrer os pobres, mas comportavam quase todas as células de detenção e casernas.

Nada mais simbólico do que a declaração feita pelo narrador de Ensaio sobre a cegueira quando as personagens notam que o manicômio fora abandonado pelos militares: o portão está aberto de par em par, os loucos saem (SARAMAGO, 1995, p. 210). O narrador nomeia-os loucos, reforçando mais ainda o tratamento desumano que os acometidos pelo mal branco receberam dos militares a mando do Governo.

Na ficção científica brasileira a "modernização aliada à ciência e tecnologia são vistas com tendo um efeito negativo nas relações sociais, destruindo o contato pessoal" (GINWAY, 2005, p.39). Em A escuridão, o estranho fenômeno desaparece, a luz volta ao mundo sem nenhuma explicação de suas causas. Assim, 
a personagem principal retornando à cidade indaga-se como conseguira sobreviver na escuridão e conclui:

Suas científicas certezas nada mais valiam. Naquele mesmo instante homens combalidos faziam funcionar computadores eletrônicos, microscópios pesquisavam lâminas, religiosos em seus templos explicavam a vontade de Deus, políticos redigiam decretos, mães choravam os mortos que permaneceram nas trevas" (CANEIRO, 1963, p.160)

Wladas, no início do conto, recorda certa revolução ocorrida em sua juventude, revolução "feita com tiros e bombardeios" (CARNEIRO, 1963, p.115). Para ele, a experiência da cegueira foi completamente diferente de qualquer outra: a revolução que se processa diante da escuridão é uma mudança no interior do indivíduo, ou, uma revolução na natureza humana que reencontra sua essência na vida de cooperação comunitária.

A escuridão aproxima os estranhos "aquela animação geral, o assunto único dominando as conversas, aproximando a todos, era um espetáculo humano que fazia esquecer as inquietudes do amanhã" (CARNEIRO, 1963, p.116). Carneiro ironiza: a personagem sente-se mal, triste, pela falta do caos urbano, que já se acostumara: "Deveria ser a ausência de trânsito, nenhum bonde ou automóvel a passar nas ruas, e gritos e vozes distantes..." (CARNEIRO, 1963, p. 117). As demonstrações de resignação ao próximo são demonstradas inicialmente pelo próprio Wladas quando este acolhe toda uma família vizinha em sua casa e a alimenta, recebendo a gratidão da mesma.

A escuridão the trouxe a consciência da alteridade: "as palavras, no negrume, são elos de presença e companhia (CARNEIRO, 1963, p.126). O esclarecimento racional, além de nada servir para explicar os estranhos fenômenos da escuridão, somente causou o distanciamento humano, a reificarão das relações. O consolo humano veio não da ciência, mas dos laços que se desenvolveram com a ausência de luz.

Apesar de antíteses, cegueira negra e cegueira branca, ambas as construções ficcionais cumprem o papel de fazer o homem encarar sua própria face, ou natureza, apesar do enfoque divergente em cada obra. Ainda assim, notamos em ambas a forte presença da crítica a pretensa evolução humana, em relação à ciência e tecnologia e como estas não necessariamente trouxeram melhorias a aspectos morais e éticos. 
José Saramago e André Carneiro criticam o racionalismo ocidental que não cumpriu a promessa de evolução humana, mas sim culminou em barbárie. Ressalta-se a diferença inerente de cada gênero literário do corpus aqui analisado; Saramago, escreve um romance, estrutura que possibilita o aprofundamento de questões que no conto de André Carneiro são somente pontuadas, como a elucidação da natureza humana, que fora analisada. André Carneiro foca na possibilidade de o ser humano reencontrar com seus aspectos positivos, Saramago, também apresenta tais atos de solidariedade e reencontro com a alteridade, como surge no pequeno grupo guiado pela mulher do médico, porém colocando estes feitos positivos como uma pequena ilha em meio à barbárie que assola toda a humanidade.

Em entrevista ao jornal de Folha de São Paulo, José Saramago ao ser questionado sobre o que se tratava sua obra Ensaio sobre a Cegueira, declara que certo dia estava num restaurante e se perguntou:

\begin{abstract}
E se fossemos todos nós cegos? Mas nós estamos todos cegos! Portanto (o livro) não tem que ver com qualquer fato da vida moderna atual, ou pretérita... eu diria que é uma cegueira história, [...] nós matamos por prazer, por gosto. Vivemos na delinquência, na violência. Como é possível a razão levar-nos a isso?! Então nesse restaurante, colocado a questão com a limpidez absoluta: e se nós fossemos todos cego? Mas nós somos cegos... Cegos da razão. Não usamos a razão para defender a vida, usamos a razão para destrui-la de todas as maneiras, no plano privado, no plano coletivo. É sobre isso que foi escrito o Ensaio sobre a cegueira ${ }^{4}$
\end{abstract}

A cegueira, branca ou negra, fora fundamental para que as personagens pudessem enxergar e promover revolução em si. A mulher do médico de Ensaio sobre a cegueira, ao ser questionada por que foi que cegaram, conclui: "Penso que não cegamos, penso que estamos cegos, Cegos que veem, Cegos que, vendo, não veem. (SARAMAGO, 1995, p.310). A razão ou a ciência positiva não mais impera como guia único da vida humana, pois "acima das especulações racionais, vinha o mistério do sangue correndo, o prazer de amar, realizar coisas, agitar os músculos e sorrir" (CARNEIRO, 1986, p. 160). Entendemos assim, a cegueira branca como metáfora para o estado totalitário que a ciência alcançou na pós-modernidade; a ciência, não surge mais como preceito questionador da realidade, mas como

\footnotetext{
${ }^{4}$ https://www.youtube.com/watch?v=BOLhNxBo6Xo acesso em 19 de março de 2018.
} 
verdade posta e dogmática. A personagem Wladas, ao final da narrativa, sobrepõe aos aspectos racionais os mistérios, as emoções e prazeres humanos irracionais.

\section{CONSIDERAÇÕES FINAIS}

A partir da análise apresentada, percebe-se que Ensaio sobre a cegueira apresenta um mundo moderno cego pelo excesso de luz. O mar de leite saramaguiano revela a profundidade e a impossibilidade de o homem conseguir enxergar o outro; não pela escuridão, mas pelo excesso do racionalismo.

Para os autores da Escola de Frankfurt, encontram-se na própria formação civilizatória do homem as bases para a barbárie; o Século XX, com as Grandes Guerras e seus estados totalitários seriam grandes exemplos de tais barbáries. A conversão do esclarecimento em comportamento de massa, ou uma consciência não crítica controlada pela Indústria Cultural encontra sua metáfora na cegueira branca: alguns destes cegos não o são apenas dos olhos, também o são do entendimento (SARAMAGO, 2010, p.213).

Assim, no romance, em um curto prazo, o mundo converte-se em uma total barbárie. A evolução técnico-científica do progresso da civilização culminou nas maiores barbáries da história: as duas grandes guerras do Século XX. A sociedade que Adorno e Horkheimer descrevem em suas críticas é a sociedade massificada, cega do entendimento, pois não fórmula críticas, mas apenas pacificamente consome. O "cego de venda preta", pode ainda ser simbolicamente comparado ironia amarga típica do texto saramaguiano - com a deusa da Justiça, Themis, representada vendada. Ainda que vendada, nada garante sua equidade perante a cegueira da alienação massificada.

A escuridão que recai sobre o mundo no conto de André Carneiro deixa a humanidade em uma cegueira negra, assim as personagens ficam desorientadas na escuridão total. Porém, a despeito da angústia e desespero de tal situação, a personagem principal de $A$ escuridão, Wladas, inicia um processo de autodescoberta, onde todo o entendimento racional do mundo é questionado - não consegue explicar o fenômeno - e logo nota aspectos positivos com a convivência com outros que eram geralmente ignorados, como os vizinhos com seus filhos, que 
logo o adotam como "tio Wladas", e os cegos de nascença, pelos quais passava sem notá-los. A escuridão lhe confere uma "visão" diferente do cotidiano.

Diante da incompreensão da ciência, as verdades são questionadas e a ciência não consegue explicar, ou esclarecer, todos os fenômenos. Neste aspecto, encontramos convergências entre as obras analisadas. Saramago expressa ironia em relação à ciência; exemplo disso é a função inútil do oftalmologista em meio a situação; este é objeto de escárnio, como expresso por um paciente, que necessitava de uma operação de catarata: "Se há remédio para isto, precisamos ambos dele", (SARAMAGO, 1995, p. 100).

A privação pelo excesso ou pela falta de luz, em cada obra, gera mudanças profundas nas personagens. As duas obras focam comportamentos humanos distintos; as reações perante a cegueira mostram-se antagônicas: regressão ao caos e barbárie, em Saramago; e retorno ao cosmos comunitário e cooperativo, em Carneiro.

\section{FROM DARKNESS TO THE LIGHT BLINDNESS: ESSAYS ON BLINDNESS IN ANDRÉ CARNEIRO AND JOSÉ SARAMAGO}

ABSTRACT: In 1963, Brazilian writer André Carneiro publishes The Darkness (A Escuridão), a short story which narrates a phenomenon that defies science: no light source, natural or artificial, illuminates anymore. Sun, matches, flashlights are useless; thereby, an unprecedented darkness falls on earth. More than thirty years later, the Portuguese writer José Saramago publishes Essay on Blindness (Ensaio sobre a cegueira), a novel that brings the drama of a world suddenly afflicted by an epidemic referred to as "white blindness". Working on similar themes, both contemporary authors open their fictional universes with reflections on the human condition and on how its nature is revealed through the collapse of political and social conventions. This article aims to analyze the points of convergence and divergence between the literary works The Darkness and Blindness from the perspective of Adorno and Horkheimer's Dialectic of Enlightenment (1944), as well as discussions of science fiction pointed by the literary critic Elizabeth Ginway. The notes of the sociologist Zygmunt Bauman (2003) will also be consulted.

KEYWORDS: André Carneiro. José Saramago. Blindness. Dialectic of Enlightenment.

\section{REFERÊNCIAS}

ADORNO, Theodor W, HORKHEIMER, Max. A dialética do esclarecimento. Rio de Janeiro: Jorge Zahar Editor, 2006.

BAUMAN, Zygmunt. Comunidade: a busca por segurança no mundo atual. Ed., Rio de Janeiro, Zahar, 2003. 
CARNEIRO, André. Diário da Nave Perdida. São Paulo: EdArt,1963.

mimeografado.

Introdução a estudo da "Science Fiction". 2004. Texto

CAUSO, Roberto de Sousa. Os melhores contos de ficção científica: fronteiras. São Paulo: Devir, 2009.

FOUCAULT, Michel. História da loucura. Ed. Perspectiva - São Paulo, 2009

GINWAY, M. Elizabeth. Ficção Científica Brasileira: Mitos Culturais e Nacionalidade no País do Futuro. São Paulo: Devir Livraria, 2005.

KANT, I. O que é o Esclarecimento? In: Textos Seletos. Trad. De Raimundo Vier. Petrópolis: vozes, 1985.

LOBATO, Monteiro. O presidente negro. São Paulo: Globo, 2008.

PERRONE-MOISÉS, Leyla. As artemages de Saramago. In.: Inútil poesia. São Paulo: Cia. das Letras, 2000. p. 182-196.

SARAMAGO, José. Ensaio sobre a Cegueira. São Paulo: Companhia das Letras, 2010.

WELLS, Herbert George. Em terra de cego. Trad. Renato Pompeu. In: CALVINO, Italo (Org.). Contos fantásticos do século XIX. São Paulo: Companhia das Letras, 2008.

WYNDHAM, John. O dia das Triffids. Trad. José Manuel Calafate. Coleção Argonauta, 1962.

Data da Submissão: 31/03/2018

Data da Aprovação: 26/07/2018 